\title{
PEMBERDAYAAN KELOMPOK KARANG TARUNA DALAM MEWUJUDKAN DESA MANDIRI DI DESA MANDING DAYA KECAMATAN MANDING
}

\author{
Oleh : \\ Raudatur Rohmah, Ida Syafriyani, Ach. Andiriyanto \\ Fakultas Ilmu Sosial dan Ilmu Politik Program Studi Administrasi Publik Universitas \\ Wiraraja Madura \\ Email : raudaturrohmah17@gmail.com, ida.fisipunija@gmail.com
}

\begin{abstract}
Community empowerment is an important thing to do because through empowerment, people's lives become better. Conceptual empowerment in essence discusses how individuals, groups or communities try to control their own lives and seek to shape the future according to their wishes. The purpose of this study was to find out how to empower youth groups in realizing an independent village in Manding Daya village, Manding sub-district. The focus in this research uses the Chabib Sholeh theory (2014: 81) which suggests three scopes of community empowerment activities, namely; a) Increasing Role in Each Activity, b) Increasing Efficiency and Effectiveness, c) Increasing Self Competence Automatically. The method in this study uses descriptive qualitative research. Data collection techniques used were observation at the research site, interviews with relevant informants and documentation. The data analysis technique used in this study uses data reduction, data presentation and conclusion drawing/data verification. The results of the research that have been carried out include a) Increasing the Role in Each of these Activities in the Youth Organization's empowerment program in the field of catfish cultivation is quite maximal. $b$ ) Increasing Efficiency and Effectiveness is a program carried out by Karang Taruna, one of which is socialization of catfish farm waste managed by Karang Taruna which is disposed of to TPS (Waste Processing Sites) with the 3R (Reduce, Reuse, Recycle) method. c) Automatic Self Competence Improvement supported by the facilities provided by the Manding Daya Village Government. In this case, it is proven by a comparative study which was attended by youth of Karang Taruna in Manding Daya Village.
\end{abstract}

Keywords: Empowerment, Youth Organization

\begin{abstract}
Abstrak
Pemberdayaan masyarakat merupakan hal yang penting untuk dilakukan karena melalui pemberdayaan, kehidupan masyarakat menjadi lebih baik. Pemberdayaan secara konseptual pada intinya membahas bagaimana individu, kelompok atau komunitas berusaha mengontrol kehidupan mereka sendiri dan mengusahakan untuk membentuk masa depan sesuai dengan keinginan mereka. Tujuan penelitian ini adalah untuk mengetahui Bagaimana Pemberdayaan kelompok karang taruna dalam mewujudkan desa mandiri di desa manding daya kecamatan manding. Fokus dalam penelitian menggunakan Teori Chabib Sholeh (2014:81) yang mengemukakan tiga lingkup kegiatan pemberdayaan masyarakat yaitu; a) Peningkatan Peran Dalam Setiap Kegiatan, b) Peningkatan Efisiensi dan Efektifitas, c) Peningkatan Kompetensi Diri Secara Otomatis. Metode dalam penelitian ini menggunakan penelitian deskriptif kualitatif. Teknik pengumpulan data yang digunakan adalah observasi di lokasi penelitian, wawancara terhadap informan-informan yang terkait dan dokumentasi.Teknik analisis data yang digunakan dalam penelitian ini menggunakan reduksi data, penyajian data dan penarikan kesimpulan/verifikasi data. Hasil penelitian yang telah dilakukan, yakni meliputi a)
\end{abstract}


Peningkatan Peran Dalam Setiap Kegiatan ini dalam program pemberdayaan Karang Taruna di bidang budidaya lele sudah cukup maksimal. b) Peningkatan Efisiensi dan Efektifitas ini yaitu program yang dilakukan oleh Karang Taruna salah satunya sosialisasi dari limbah peternakan ikan lele yang dikelola oleh Karang Taruna yaitu di buang ke TPS (Tempat Pengolahan Sampah) dengan metode 3R (Reduce,Reuse, Recycle). c) Peningkatan Kompetensi Diri Secara Otomatis yang didukung oleh fasilitas yang telah disediakan oleh Pemerintah Desa Manding Daya.Dalam hal ini dibuktikan dengan adanya studi banding yang diikuti oleh remaja Karang Taruna Desa Manding Daya.

Kata Kunci : Pemberdayaan, Karang Taruna

\section{PENDAHULUAN}

Indonesia sebagai negara agraris dan maritim terkenal akan kekayaan alam dan hasil bumi yang melimpah, hasil bumi seperti batu bara, emas, minyak dan gas alam adalah sebagai bukti bahwa Indonesia memiliki potensi tinggi dalam kekayaan alam.Dengan adanya potensi yang dimiliki diharapkan mampu mendorong pembangunan nasional dalam mewujudkan masyarakat yang sejahtera. Meskipun potensi yang dimiliki sangat melimpah, masih belum bisa meningkatkan kesejahteraan masyarakat yaitu ditandai masih banyaknya angka kemiskinan. Hal tersebut dapat dibuktikan dengan data BPS Tahun 2020 yang menunjukkan bahwa angka kemiskinan Indonesia adalah sebesar Rp 2.216.714.

Salah satu upaya pemerintah untuk mengetaskan kemiskinan ini adalah melalui pemberdayaan masyarakat dengan cara memberikan pelatihan pada masyarakat serta meningkatkan motivasi dan minat belajar masyarakat. Pemuda desa menjadi faktor utama dalam kesuksesan pembangunan desa. Pemuda memiliki peran yang sangat penting dalam pembangunan masyarakat, dimanapemuda merupakan generasi penerus peradapan suatu masyarakat. Pemuda juga merupakan pelopor dalam setiap perubahan, yang bekerja, dan semangatnya yang luar biasa membuat pemuda ikut menentukan masa depan suatu bangsa. Remaja merupakan generasi yang akan mewarisi negara Indonesia pada masa yang akan datang.

Permasalahan pemuda desa pada masa sekarang ini adalah rasa malas dan kurang peduli terhadap lingkungan sehingga pemuda desatidak begitu peka terhadap potensi yang ada. Dalam memecahkan masalah generasi muda diperlukan suatu wadah untuk membina dan mengarahkan generasi muda tersebut.

Pelaksanaan pembinaan tersebut merupakan tugas dan kewajiban pengurus pelaksana baik dari tingkat pusat maupun daerah yang sesuai dengan bidangnya, yang diterjemahkan ketengah masyarakat terutama dalam pemberian bantuan dan bimbingan yaitu dengan membentuk suatu organisasi yang nantinya akan menjadi wadah pembinaan generasi muda 
tersebut khususnya di pedesaan.

Pemberdayaan

masyarakat

merupakan hal yang penting untuk dilakukan karena melalui pemberdayaan, kehidupan masyarakat menjadi lebih baik.Pemberdayaan yang dilaksanakan sesuai dengan prosedur dan model pemberdayaan partisipatif salah satunya kegiatan pemberdayaan pembudidaya ikan (Zulkarnain, 2015).Menurut M Saleh Marzuki (2010:88) menyatakan bahwa "pemberdayaan atau empowernment berarti pemberian daya atau kekuatan kepada seseorang karena dia dianggap tidak berdaya atau kekuatan yang ada sangat kecil sehingga hampir tidak bisa berbuat apa-apa".

Secara sederhana, adanya kegiatan pemberdayaan adalah bagaimana membuat individu yang tidak berdaya menjadi lebih berdaya, artinya pemberdayaan memberikan suatu proses individu untuk mengembangkan kemampuannya supaya lebih berdaya atau berkemampuan.

Menurut buku pedoman Karang Taruna 2010, yang dimaksud Karang Taruna adalah organisasi sosial sebagai wadah pengembangan potensi generasi muda yang tumbuh dan berkembang atas dasar kesadaran jiwa dan tanggung jawab sosial, dari, oleh, dan untuk masyarakat terutama generasi muda yang berada di wilayah desa atau komunitas atau setingkat dan juga bergerak dalam bidak kesejahteraan sosial guna kemajuan bersama.Jadi pada intinya selain menampung aspirasi, karang taruna juga berperan sebagai suatu wadah untuk menanamkan rasa nasionalisme, pengembangan potensi diri dan merupakan organisasi yang bergerak di bidang sosial.

Dengan adanya pemberdayaan masyarakat ini dapat menjadi jembatan menuju sebuah desa mandiri. Pengertian desa mandiriMenurut keputusan menteri PDTT Nomor 16 Tahun, Desa Mandiri adalah desa maju yang memiliki kemampuan melaksanakan pembangunan desa untuk peningkatan kualitas hidup dan kehidupan sebesar besarnya kesejahteraan masyarakat desa dengan ketahanan ekonomi, dan ketahanan ekologi secara berkelanjutan.

Salah satu desa yang menginginkan terwujudkan desa menjadi desa mandiri adalah Desa Manding Daya Kecamatan Manding Kabupaten Sumenep. Potensi desa yang dimiliki oleh desa Manding Daya adalah padi, singkong, dan kacang- kacangan. Di Desa Manding Daya terdapat organisasi Karang Taruna yang menjadi organisasi pengembangan serta pemberdayaan bagi amsyarakat desa terutama para pemuda desa.Anggotanya terdiri dari para 
pemuda/pemudi yang kebanyakan putus sekolah dan tidak mempunyai pekerjaan tetap.

Hal tersebut yang menjadi indicator ketidakberdayaan masyarakat desa manding sehingga untuk mewujudkan desa mandiri dilakukan adanya pemberdayaan pada masyarakat desa tersebut. Organisasai Karang Taruna di Desa Manding Daya ini sudah mulai merintis berbagai usaha, seperti usaha pembenihan ikan lele di kolam terpal.Salah satu karang taruna yang sekarang digeluti adalah kelompok usaha pembenihan ikan lele.Saat ini, anggota karang taruna yang aktif menggeluti usaha pembenihan ikan lele, masing-masing anggota kelompok hanya mempunyai 1-2 kolam terpal $2 \times 3 \mathrm{~m}^{2}$.

\section{TINJAUAN TEORITIS}

\subsection{Pengertian Pemberdayaaan}

\section{Masyarakat}

Pemberdayaan adalah sebuah proses agar setiap orang menjadi cukup kuat untuk berpartisipasi dalam berbagai pengontrolan, dan mempengaruhi, kejadian-kejadian serta lembaga- lembaga yang mempengaruhi kehidupannya.

Pemberdayaan menekankan bahwa orang memperoleh keterampilan, pengetahuan, dan kekuasaan yang cukup untuk mempengaruhi kehidupannya dan kehidupan orang lain. Menurut Slamet dalam buku Totok Mardikanto, pemberdayaan adalah upaya yang dilakukan oleh masyarakat, dengan atau dukungan pihak luar, untuk memperbaiki kehidupannya yang berbasis kepada daya mereka sendiri, melalui upaya optimasi daya serta peningkatan posisitawa yang ini yang menjadi perhatiannya, pemberdayaan harus menempatkan kekuatan masyarakat sebagai modal utama sertamenghindari "rekayasa" pihak luar yang seringkali mematikan kemandirian masyarakat setempat.

Adapun menurut Sumodiningrat dalam buku Totok Mardikanto dan Poerwoko Soeboato, mengatakan bahwa pemberdayaan merupakan upaya pemberian kesempatan atau memfasilitasi kelompok miskin agar mereka memiliki aksesibilitas terhadap sumberdaya, yang berupa: modal teknologi, informasi, jaminan pemasaran dan lain-lain, agar mereka mampu memajukan dan mengembangkan usahanya, sehingga memperoleh perbaikan pendapatan serta perluasan kesempatan kerja demi perbaikan kehidupan dan kesejahteraannya.

Pengertian pemberdayaan di atas, menekankan pada pemberian kesempatan, kekuasaan, agar masyarakat berdaya sehingga dapat mengatur diri sendiri dan lingkungannya sesuai keinginan, potensi dan kemampuan yang dimiliki. Pemberdayaan tidak hanya memberikan 
wewenang kepada pihak yang tidak berdaya saja. Tetapi dalam suatu pemberdayaan mempunyai makna adanya proses pendidikan, yakni masyarakat di berikan pengetahuan dalam menjalankan proses pelaksanaan budidaya ikan lele agar dapat meningkatkan kualitas individu, kelompok, atau masyarakat sehingga dapat berdaya, memiliki daya saing, dan hidup mandiri.

\subsubsection{Mekanisme Kegiatan}

\section{Pemberdayaan Masyarakat}

Menurut Chabib Sholeh (2014 : 90)

mekanisme kegiatan pemberdayaan masyarakat terdiri atas beberapa tahapan kegiatan yang pada dasarnya merupakan siklus yang senantiasa berulang tetap. Tahapan-tahapan yang dimaksud adalah :

1. Peningkatan peran dalam setiap kegiatan

$\begin{array}{lr}\text { Keterlibatan } & \text { secara } \\ \text { sadar terhadap } & \text { suatu } \\ \text { kegiatan dalam } & \text { proses } \\ \text { perubahan } & \text { menuju } \\ \text { kehidupan yang lebih baik, } \\ \text { akan meningkat dengan } \\ \text { sendirinya apabila mereka } \\ \text { telah merasakan manfaat } \\ \text { (ekonomi dan sosial). Ada } \\ \text { baiknya bagi } \\ \text { pemberdaya para } \\ \text { mempertemukan mereka } \\ \text { dengan orang yang telah } \\ \text { berhasil dan mandiri } \\ \text { untuk saling berbagi }\end{array}$

pengalaman tentang suka dan duka mereka

dalam pemberdayaan.

Kegiatan budidaya lele yang dilaksanakan Karang Taruna mengutamakan atau memaksimalkan peran anak muda karena dianggap hampir setiap wilayah di Desa Manding Daya memiliki generasi muda yang sangat aktif dan produktif karena memiliki tenaga, antusias dan semangat yang tinggi.

2. Peningkatan efisiensi dan efektifitas

Sebagaimana kita ketahui setiap manusia memiliki tujuan yang tidak terbatas, sementara sumberdaya untuk mewujudkan tujuan tersebut terbatas adanya.Oleh karena itu, penggunaan sumberdaya yang terbatas itu harus dilakukan dengan seefisien dan seefektif. Hal ini mengisyaratkan akan pentingnya suatu metode atau teknologi yang tepat agar 
sumberdaya yang ada dapat dihemat sebaik mungkin. Program yang dilakukan oleh Karang Taruna salah satunya sosialisasi yang disini program Karang Taruna saat ini yaitu TPS (Tempat Pengolahan Sampah) 3R (Reduce, Reuse, Recycle) disitu aka nada program pemberdayaan dan pemanfaatan kembali sampah- sampah yang sudah di pilah oleh Karang Taruna yang akan nantinya hasilnya juga akan dirasakan oleh masyarakat desa.

3. Peningkatan kompetensi diri secara otomatis

$\begin{array}{cr}\text { Pada } & \text { akhirnya } \\ \text { pemberdayaan } & \text { harus }\end{array}$
mampu meningkatkan kapasitas diri secara otomatis pada pihak yang diberdayakan.Hal ini dapat terjadi apabila, mereka sudah merasakan manfaat langsung maupun manfaat tidak langsung yaitu berupa peningkatan kapasitas diri yang diperoleh secara otomatis baik belajar pada pengalaman yang telah mereka rasakan.

Peningkatan kompetensi diri secara otomatis yang dibuktikan oleh studi banding yangdisediakan oleh Pemerintah Desa dengan budidaya lele di ketapang Sampang. Dengan hal itu peningkatan kompetensi diri secara otomatis telah berkembang sesuai dengan harapan karena dari pihak pemerintah desapun mendukung dengan adanya studi banding yang diikuti oleh remaja Karang Taruna Desa Manding Daya.

Pemberdayaan

masyarakat merupakan hal yang penting untuk dilakukan karena melalui pemberdayaan, kehidupan masyarakat menjadi lebih baik. Pemberdayaan yang dilaksanakan sesuai dengan prosedur dan model pemberdayaan partisipative salah satunya kegiatan pemberdayaan pembudidaya ikan(Zulkarnain, 2015). 
Menurut Zubaedi

(2013 : 4) pemberdayaan masyarakat adalah suatu cara yang memungkinkan setiap orang dapat meningkatkan kualitas hidupnya serta mampu memperbesar pengaruhnya terhadap proses-proses yang mempengaruhi

kehidupannya.

Menurut Arifianto (2017) menyatakan bahwa pemberdayaan masyarakat desa dapat dilakukan dengan memberikan program-program pelatihan yang diadakan oleh perangkat desa atau lembaga lainnya untuk meningkatkan karang taruna di pedesaan.

Sumodinigrat (1997)

menyatakan bahwa hakikat dari pemberdayaan berpusat pada manusia dan kemanusiaan, dengan kata lain manusia dan kemanusiaan sebagai tolak ukur normatif, struktural, dan substansi.

\subsection{Karang Taruna}

Karang Taruna adalah organisasi sosial kemasyarakatan sebagai wadah dan sarana pengembangan setisp anggota masyarakat yang tumbuh dan berkembang atas dasar kesadaran dan tanggung jawab sosial dari, oleh, dan untuk masyarakat terutama generasi muda di wilayah desa/kelurahan terutama bergerak dibidang usaha kesejahteraan sosial. Kesejahteraan sosial ini adalah upaya terarah, terpadu, dan berkelanjutan yang dilakukan pemerintah, Pemerintah Daerah dan Masyarakat meliputi rehabilitas sosial, jaminan sosial, penguatan sosial, dan perlindungan sosial.

Pembentukan Karang Taruna dilatarbelakangi oleh banyaknya anakanak yang menyandang masalah sosial antara lain seperti anak yatim, putus sekolah, mencari nafkah membantu orang tua, dan sebagainya. Masalah tersebut tidak terlepas dari kemiskinan yang di alami sebagian masyarakat kala itu.Pada tahun 2005, Menteri Sosial mengeluarkan Peraturan Menteri Sosial RI Nomor 83/HUK/2005 tentang Pedoman Karang Taruna. Pengakuan terhadap Karang Taruna ini dibuktikan dengan masuknya nama Karang Tauna dalam beberapa regulasi atau perundang-undangan.

Undang-Undang Nomor 6 Tahun 2014 bertujuan untuk mengoptimalkan penyelenggaraan Desa, pelaksanaan pembangunan desa, pembinaan kemasyarakatan desa, dan pemberdayaan masyarakat Desa. Artinya dalam Undang- 
Vol 16, nomor 2, Desember 2021

Undang Republik Indonesia Nomor 6 Tahun 2014 mengatur semua aspek pemerintahan desa yang berkaitan dengan pemerintahan desa, pelaksanaan pembangunan desa, pembinaan kemasyarakatan desa dan pemberdayaan masyarakat desa.

Saat ini di Desa Manding Daya harus lebih berkembang dalam berbagai bentuk, sehingga perlu dilindungi dan diberdayakan agar menjadi kuat, maju, mandiri, dan demokratis, karena Karang Taruna di Desa Manding Daya masih berjalan 1 tahun jadi masyarakat masih kurang tau dengan adanya Karang Taruna. Tujuannya adalah agar Desa dapat menciptakan landasan yang kuat dalam melaksanakan pemerintahan dan pembangunan menuju masyarakat yang adil, makmur, dan sejahtera. Untuk itulah kemudian terbit Undang-Undang Republik Indonesia Nomor 6 Tahun 2014 tentang desa (Ramli : 2014 : 137).

Pengertian Karang Taruna menurut Peraturan Menteri Sosial Republik Indonesia Nomor: 23 Tahun 2013tentang Pemberdayaan Karang Taruna, Pasal 1 angka (1)menyebutkan bahwa:"Karang Taruna adalah organisasi sosialkemasyarakatan sebagai wadah dan saranapengembangan setiap anggota masyarakat yangtumbuh dan berkembang atas dasar kesadarandan tanggung jawab sosial dari, oleh, dan untukmasyarakat terutama generasi muda di wilayahdesa atau kelurahan".
ISSN 2443-0714 E-ISSN 2621-475X

Untuk itu Karang Taruna harus melaksanakan strateginya secara optimal agar mampu membina generasi muda agar menjadi generasi penerus yang berakhlak danmampu memimpin bangsa di masa yang akan datang.

\subsection{Desa Mandiri}

Menurut keputusan menteri PDTT Nomor 16 Tahun, Desa Mandiri adalah desa maju yang memiliki kemampuan melaksanakan pembangunan desa untuk peningkatan kualitas hidup dan kehidupan sebesar-besarnya kesejahteraan masyarakat desa dengan ketahanan ekonomi, dan ketahanan ekologi secara berkelanjutan. Desa mandiri juga dapat di artikan sebagai desa yang juga mampu mengatur dan membangun desanya dengan memaksimalkan potensi yang ada di desa dan kemampuan masyarakatnya dan tidak bergantung pada bantuan pihak luar.Selain itu desa mandiri dapat di artikan sebagai desa yang mampu menghasilkan produk yang berdaya saing, lembaga sosial yang aktif, tingkat partisipasi, keswadayaan masyarakat tinggi dan masyarakat miskin terlibat aktif dalam rantai produksi (Basuki Sigit Priyono, dkk (2019:8)).

Pembangunan perdesaan adalah suatu strategi yang memungkinkan kelompok masyarakat miskin di desa, memperoleh apa yang mereka inginkan dan perlukan bagi drinya maupun 
Vol 16, nomor 2, Desember 2021

anakanaknya. Strategi ini merupakan upaya untuk menolong golongan di antara mereka yang mencari kehidupan di daerah perdesaan untuk menguasai lebih banyak manfaat dari hasil pembangunan.

\section{Sedangkan menurut Borni}

Kurniawan dalam Buku 5 Desa Mandiri, Desa Membangun terdapat empat strategi yang dapat dilakukan untuk mewujudkan desa mandiri yaitu :

a. Membangun kapasitas warga dan organisasi masyarakat sipil di desa yang kritis dan dinamis. Kedua hal tersebut merupakan modal penting bagi desa untuk membangun kedaulatan dan titik awal terciptanya komunitas warga desa yang nantinya akan menjadi kekuatan penyeimbang atas munculnya kebijakan publik yang tidak responsif terhadap masyarakat.

b. Memperkuat kapasitas

pemerintahan dan interaksi dinamis antara organisasi warga dalam penyelenggaraan pemerintahan desa. Menguatnya kapasitas pemerintah desa tentu tidak hanya tercermin pada kemampuan teknokratis aparatur desa dalam membuat perencanaan program atau

kegiatan pembangunan. Akan tetapi, tercermin pula pada peran
ISSN 2443-0714 E-ISSN 2621-475X

BPD membangun proses perumusan dan pengambilan kebijakan yang dinamis keterpaduan interaksi yang dinamis antara organisasi warga desa dengan pemerintah desa juga tercermin dalam berbagai inisiatif lokal lainnya.

c. Membangun sistem perencanaan dan penganggaran desa yang responsif dan partisipatif. Menuju sebuah desa mandiri dan berdaulat tentu membutuhkan sistem perencanaan yang terarah di topang partisipasi warga yang baik. Sebelum Undang-Undang No. 6 Tahun 2014 tentang Desa lahir, desa telah mengenal system perencanaan pembangunan partisipatif, dimana acuan atau landasan hukumnya waktu itu adalah UU No. 32 tahun 2004 tentang Pemerintahan Daerah. Kewajiban desa membuat perencanaan pembangunan dipertegas melalui PP No.72 Tahun 2005 tentang Pemerintahan Desa sebagai regulasi teknis turunan dari UU No.32 Tahun 2004 tersebut.

d. Membangun kelembagaan ekonomi lokal yang mandiri dan produktif. Saat ini banyak sekali 
tumbuh inisiatif desa membangun keberdayaan ekonomi lokal. Keberhasilan di bidang ekonomi tersebut tidak lepas dari kemampuan desa membangun perencanaan yang konsisten, partisipatif dan disepakati dalam dokumen perencanaan dan penganggaran desa (RPJMDesa, Rencana Kerja Pemeritah Desa dan Anggaran Pendapatan dan Belanja Desa).

Berdasarkan teori-teori di atas dan melihat mengenai apa yang terjadi di lapangan, maka penulis memutuskan menggunakan teori berdasarkan UU No. 6/2014 tentang Desa. Penulis merasa bahwa teori ini dapat menjawab rumusan masalah pertama yaitu Bagaimana Pemberdaryaan Kelompok Karang Taruna Dalam Mewujudkan Desa Mandiri Di Desa Manding Daya Kecamatan Manding.

\section{METODE PENELITIAN}

Penelitian ini merupakan penelitian deskriptif kualitatif dengan teknik pengumpulan data yang menggunakan teknik observasi, wawancara, dan dokumentasi. Pada uji validitas dalam penelitian ini, peneliti menggunakan teknik triangulasi sumber, serta menganalisis data dengan cara mereduksi data, penyajian data, dan penarikan kesimpulan.

\section{HASIL DAN PEMBAHASAN}

Penelitian ini membahas lebih dalam mengenai tentang Pemberdayaan Kelompok Karang Taruna Dalam Mewujudkan Desa Mandiri Di Desa Manding Daya dengan pendekatan tiga Lingkup Kegiatan Pemberdayaan Menurut Chabib Sholeh (2014:90) :

\section{Peningkatan Peran Dalam}

\section{Setiap Kegiatan}

Peningkatan Peran Dalam Setiap Kegiatan, keterlibatan secara sadar terhadap suatu kegiatan dalam proses perubahan menuju kehidupan yang lebih baik, akan meningkat dengan sendirinya apabila mereka telah merasakan manfaat (ekonomi dan sosial). Ada baiknya bagi para pemberdaya untuk mempertemukan mereka dengan orang yang telah berhasil dan mandiri untuk saling berbagi pengalaman tentang suka dan duka mereka dalam pemberdayaan. Kegiatan yang dilaksanakan karang Taruna menjadi suatu hal yang sangat penting dalam pembentukan karakter remaja di Desa Manding Daya, baik dalam 
bidang keagamaan maupun dalam bidang sosial. Dengan melaksanakan program- program Karang Taruna diharapkan para remaja mengikuti programprogram yang dijalankan Karang Taruna dengan baik guna untuk membuat karakter yang sosial dalam berkehidupan bermasyarakat dengan baik.

Sebagaimana berdasarkan penelitian yang dilakukan oleh peneliti di dalam Karang Taruna Desa Manding Daya dalam peningkatan peran pemuda dalam kegiatan budidaya ikan lele telah dikerjakan, dalam hal ini karang taruna mengutamakan atau memaksimalkan peran anak muda karena hampir setiap wilayah di Desa Manding Daya memiliki generasi muda yang sangat aktif dan produktif,memiliki antusias dan semangat yang tinggi untuk membangun Desa Manding menjadi Desa yang labih mandiri. Peran kegiatan para pemuda desa diantaranya adalah budidaya lele, penetasan telur, ayam petelur, bebek potong dengan tujuan agar karang taruna dapat menjadikan desa manding daya ini lebih berdaya saing dan mewujudkan adanya desa mandiri. Tujuan pelatihan budidaya ikan lele kepada para pemuda adalah untuk meningkatkan kemampuan dan pemberdayaan peserta pelatihan sesuai dengan anjuran pemerintah. Setelah kegiatan pelatihan dapat memiliki pengetahuan dan keterampilan cara pembenihan ikan lele, cara pendederan ikan lele, cara pembesaran ikan lele, cara penampungan ikan lele dan cara pemasaran ikan lele.

Menurut Zulkarnain (2015) menyatakan bahwa pemberdayaan masyarakat merupakan hal yang penting untuk dilakukan karena melalui pemberdayaan, kehidupan masyarakat menjadi lebih baik. Pemberdayaan yang dilaksanakan sesuai dengan prosedur dan model pemberdayaan partisipative salah satunya kegiatan pemberdayaan pembudidaya ikan lele.Dengan adanya peningkatan peran dalam setiap kegiatan dalam hal ini eksistensi organisasi mengadakan program-program seperti pelatihan dapat menjadikan masyarakat bisa lebih mandiri.Seperti pendapat 
Arifianto (2017) menyatakan bahwa pemberdayaan masyarakat desa dapat dilakukan dengan memberikan program-program pelatihan yang diadakan oleh perangkat desa atau lembaga lainnya untuk meningkatkan karang Taruna di pedesaan.

Undang-Undang Nomor 6 Tahun 2014 bertujuan untuk mengoptimalkan penyelenggaraan desa, pelaksanaan pembangunan desa, pembinaan kemasyarakatan desa, dan pemberdayaan masyarakat desa. Sehingga berdasarkan Undang-Undang tersebut desa dapat memanfaatkan Karang Taruna untuk memberdayakan masyarakat sehingga Karang Taruna juga telah melakukan peningkaan peran dalam menjadikan masyarakat desa lebih mandiri.

\section{Peningkatan Efisiensi dan Efektifitas}

Sebagaimana kita ketahui manusia memiliki tujuan yang tidak terbatas, sementara sumberdaya untuk mewujudkan tujuan tersebut terbatas adanya.Oleh karena itu, penggunaan sumberdaya yang terbatas itu harus dilakukan dengan seefisiensi dan seefektif. Hal ini mengisyaratkan akan pentingnya suatu metode atau teknologi yang tepat agar sumberdaya yang ada dapat di hemat sebaik mungkin.

Sebagaimana berdasarkan penelitian yang telah dilakukan dalam peningkatan efisiensi dan efektifitas ini yaitu program yang dilakukan oleh Karang Taruna salah satunya sosialisasi yang disini program Karang Taruna saat ini yaitu TPS (Tempat Pengolahan Sampah) dan 3R (Reduce, Reuse, Recycle) disitu akan ada program pemberdayaan dan pemanfaatan kembali sampah-sampah yang sudah di pilah oleh Karang Taruna yang akan nantinya hasilnya juga akan dirasakan oleh masyarakat desa. Melalui penyuluhan mengenai bank sampah akan berdampak positif baik secara ekonomi, sosial, maupun lingkungan.

Kegiatan pengabdian kepada masyarakat dikarenakan membantu dan mengajarkan masyarakat dalam memilah sampah guna menumbuhkan kesadaran masyarakat melalui pengelolaan sampah guna memperoleh manfaat secara langsung, baik secara ekonomi, terwujudnya kesehatan lingkungan yang bersih, hijau, 
nyaman, dan sehat.

Karang Taruna dan organisasi remaja masih memiliki semangat yang tinggi unuk memperbaiki desa. Kegiatan gotong royong ini dapat dilaksanakan satu bulan dua kali dan dikoordinasikan oleh Karang Taruna dan organisasi remaja serta perangkat desa agar menjadi kegiatan rutin yang dilakukan di Desa Manding Daya. Melakukan upaya pemanfaatan sampah yang bisa digunakan sebagai bahan daur ulang adalah salah satu upaya untuk mengurangi sampah.

$$
\text { Adapun menurut }
$$

Sumodiningrat dalam buku Totok Mardikanto dan Poerwoko Soeboato, mengatakan bahwa pemberdayaan merupakan upaya pemberian kesempatan atau memfasilitasi kelompok miskin agar mereka memiliki aksesibilitas terhadap sumberdaya, yang berupa modal teknologi, informasi, jaminan pemasaran dan lain-lain, agar mereka mampu memajukan dan mengembangkan usahanya, sehingga memperoleh perbaikan pendapatan serta perluasan kesempatan kerja demi perbaikan kehidupan dan kesejahteraannya. Dengan adanya peningkatan efisiensi dan efektifitas pemberdayaan Karang Taruna diharapkan mampu mengefisiensikan dan mengefektiviaskan misi dan visi Karang Taruna dalam memberdayakan dan menjadikan masyarakat agar bisa lebih mandiri dan berkembang.Dalam hal ini di harapkan pemberdayaan yang dilakukan untuk Karang Taruna di Desa Manding Daya dapat terlaksana secara efisiensi dan efektifitas.

\section{Peningkatan Kompetensi Diri}

\section{Secara Otomatis}

Peningkatan secara otomatis dalam kompetensi diri yang dilakukan oleh pemerintah desa Manding Daya dalam upaya pengembangan Karang Taruna telah dilakukan.Hal ini dibuktikan dengan adanya dukungan penuh oleh Kepala Desa dalam setiap program atau kegiatan dalam mewujudkan desa mandiri.Peran remaja di Desa Manding Daya sangat di butuhkan dalam implementasi pengembangan karang taruna.Pemberdayaan karang taruna diharap mampu meningkatkan kapasitas diri 
secara otomatis.

Sebagaimana berdasarkan yang telah dilakukan dalam peningkatan kompetensi diri secara otomatis yang dilakukan dengan studi banding yang dilakukan untuk pemerintah desa Manding dengan pemerintah desa di ketapang Sampang yaitu berupa studi banding budidaya lele dengan adanya studi banding ini pemuda Karang Taruna dapat memperoleh atau bertukar ilmu baru tentang bagaimana cara membudidayakan lele agar lebih baik sehingga lele yang dihasilkan memiliki kualitas yang cukup bagus.

Menurut Zubaedi (2013 : 4) pemberdayaan masyarakat adalah suatu cara yang memungkinkan setiap orang dapat meningkakan kualitas hidupnya serta mampu memperbesar pengaruhnya terhadap proses-proses yang mempengaruhi kehidupannya. Dengan adanya peningkatan kompetensi diri secara otomatis pemberdayaan Karang Taruna untuk mengembangkan inovasiinovasinya dalam hal apapun selagi itu kegiatan positif contohnya budidaya lele. Jadi Kepala Desa ketika Karang Taruna akan mengembangkan budidaya lele

\section{bapak}

Kepala

Desa

mengeluarkan dana pribadi untuk modal utama kegiatan budidaya lele.Untuk sarana dan prasarana yang di berikan bapak Kepala Desa sangatlah memuaskan.Dan itupun ada sebagian tidak berbentuk tempat atau lahan untuk Karang taruna.

\section{PENUTUP}

Berdasarkan hasil penelitian yang telah dilakukan dan dipaparkan pada bab sebelumnya, maka penulis dapat menarik kesimpulan sehubungan dengan permasalahan penelitian tentang Pemberdayaan Kelompok Karang Taruna Dalam Mewujudkan Desa Mandiri terkait dengan fokus kajian yang mengacu pada Buku Pembangunan dan Pemberdayaan Teori Chabib Sholeh (2014:90) yang mengemukakan tiga lingkup kegiatan pemberdayaan masyarakat yaitu sebagai berikut :

1. Peningkatan Peran Dalam Setiap Kegiatan

Peningkatan peran dalam setiap kegiatan ini dalam program pemberdayaan karang taruna di bidang budidaya lele sudah cukup maksimal.Dengan mengutamakan atau lebih 
Vol 16, nomor 2, Desember 2021

cenderung memaksimalkan peran anak muda karena dianggap sangat produktif dan memiliki semangat yang tinggi.

2. Peningkatan Efisiensi dan Efektifitas

Peningkatan efisiensi dan efektifitas ini yaitu program yang dilakukan oleh Karang Taruna salah satunya sosialisasi dari limbah peternakan ikan lele yang dikelola oleh Karang Taruna yaitu dibuang ke TPS (Tempat Pengolahan Sampah) yaitu dengan metode 3R (Reduce, Reuse, Recycle) dalam hal ini limbah akan dimanfaatkan kembali oleh pihak pengelolah sampah sehingga pihak pengelola sampah akan diuntungkan dengan adanya limbah tersebut yang dapat digunakan dan dikelolah menjadi barang yang bermanfaat berupa pupuk organik alami.

3. Peningkatan Kompetensi Diri Secara Otomatis

Peningkatan kompetensi diri secara otomatis yang didukung oleh fasilitas yang telah disediakan oleh Pemerintah Desa Manding Daya.Dalam hal ini dibuktikan dengan adanya studi
ISSN 2443-0714 E-ISSN 2621-475X

banding yang diikuti oleh remaja Karang Taruna Desa Manding Daya.Dalam upaya peningkatan kompetensi diri secara otomatis dapat berkembang sesuai dengan harapan.

Berdasarkan uraian dari hasil penelitian dan kesimpulan diatas, maka penulis memberikan saran sehubungan dengan permasalahan penelitian tentang Pemberdayaan Kelompok Karang Taruna Dalam Mewujudkan Desa Mandiri terkait dengan fokus kajian yang mengacu pada Buku Pembangunan dan Pemberdayaan Teori Chabib Sholeh (2014:90) yang mengemukakan tiga lingkup kegiatan pemberdayaan masyarakat yaiu sebagai berikut :

1. Peningkatan Peran Dalam Setiap Kegiatan

Peningkatan peran dalam setiap kegiatan ini dalam program pemberdayaan Karang Taruna di bidang budidaya lele ini harus lebih di maksimalkan.Karena tenaga mereka masih segar-segarnya dan semangat mereka lebih tinggi-tingginya.

2. Peningkatan Efisiensi dan Efektifitas

Dalam peningkatan 
efisiensi dan efektifitas ini dengan adanya program Karang Taruna yaitu TPS (Tempat Pengolahan Sampah) dengan metode 3R (Reduce, Reuse, Recycle).Dalam hal ini dapat dimanfaatkan kembali sampahsampah yang sudah di pilah oleh Karang Taruna.

3. Peningkatan Kompetensi Diri Secara Otomatis

Dalam peningkatan kompetensi diri secara otomatis ini telah di optimalkan oleh Pemerintah Desa Manding Daya dengan adanya studi banding yang dilakukan oleh remaja Karang Taruna. Karena dalam hal ini peningkatan kmpeensi diri secara otomatis lebih dilakukan secara terus- menerus.

\section{DAFTAR PUSTAKA}

\section{Buku:}

Alfitri. 2011. Community Development

Teori dan Aplikasi. Yogyakarta: Pustaka Pelajar.

Akhmad Fauzi. Ekonomi Perikanan. Jakarta: Gramedia Pustaka Utama, 2010

Anwas, Oos M .2013. Pemberdayaan Masyarakat di Era Global. Jakarta: ALFABETA cv.
Borni Kurniawan, Buku 5 Desa Mandiri, Desa

membangun, (Jakarta : Kementrian

Desa, Pembangunan Daerah

Tertinggal, dan

Transmigrasi Republik

Indonesia, 2015)

Ife, Jim dan Frank Tesoriero. 2006.

Community Development,

Yogyakarta: Pustaka Pelajar.

Marzuki, S, (2010). Pendidikan Non Formal

Dimensi dalam Keaksaran Fungsional, Pelatihan dan

Andragogi.Bandung : PT Remaja

Rosdakarya.

Sholeh, Chabib, 2014. Dialektika Pembangunan

dan Pemberdayaan. Bandung : Fokusmedia.

Sugiono, 2017.Metode Penelitian Kualitatif dan Kombinasi (Mixed Methods). Bandung: Alfabeta.

Totok Mardikanto, Poerwoko

Soebiato, Pemberdayaan Masyarakat Dalam Perspektif Kebijakan Publik (Bandung:Alfabeta, 2013),h.100. Zulkalnain.“Analisis Hubungan Jaringan Komunikasi Dengan Perubahan Penghidupan dan Pola Pikir Dalam Pemberdayaan Pembudidaya Ikan Di Kabupaten 
Kampar, Riau.Disertasi.Bogor (ID)

Sekolah Pascasarjana. Institute Pertanian Bogor. 2015.

Jurnal:

Adi, S, (2011). Analisa Usaha Perikanan

Budidaya. Jakarta: Pusat

Penyuluhan Kelautan dan Perikanan

: Kementrian Kelautan dan Perikanan.

Badan Pusat Statistik. (2018). Agustus 2018

: Tingkat Penggangguran Terbuka

(TPT) sebesar 5,34 Persen.

Didik. G. Suhart, 2016, Membangun

Kemandirian Desa (Perbandingan

UU No.5/1979, UU No. 22/1999,

\& UU No. 32/2004 serta perspektif UU

No. 6/2014, Pustaka Pelajar,

Yogykarta.

Fahrudin, Adi. 2012. Pemberdayaan Masyarakat di Lahan Gambut.Bogor : Wetlands International.

Marzuki, S. (2010).Pendidikan Non Formal Dimensi dalam Keaksaraan Fungsional, Pelatihan dan Andragogi.Bandung : PT Remaja Rosdakarya.

Najiati, Sri, dkk. 2005. Pemberdayaan Masyarakat di Lahan Gambut. Bogor: Wetlands International.

Nasdian, Fredian Tonny. 2014.

Pengembangan Masyarakat Edisi 1.
Jakarta: Yayasan Pustaka Obor Indonesia.

Noor, M. (2011). Pemberdayaan Masyarakat. Jurnal Ilmiah CIVIS, 1(2), 87-99.

Suwarsito dan A. Suyadi.(2010). Upaya

Meningkatkan Produksi Benih

Ikan Lele Dumbo (Clarias gariepinus).

Sarno, 2018.Pemberdayaan Masyarakat

Desa Pagak Banjarnegara

Melalui Transfer Teknologi

Hidroponik Sayuran

Organik.Jurnal Adimas

Pengabdian kepada Masyarakat.

Universitas Muhamaddiyah

Ponorogo, Jawa Timur, 2(1), (1-

7).

Sunyoto, U. (2004). Pembangunan dan Pemberdayaan Masyarakat. Yogyakarta: Pustaka Pelajar.

Arsip Pemerintahan:

Peraturan Menteri Sosial RI No.

77//HUK/2010

Tentang

Pedoman Dasar Karang Taruna.

Undang-Undang Republik Indonesia

Nomor 6 Tahun 2014 Tentang

Desa. 